\title{
Nitric Oxide Production in Host-Versus-Graft and Graft-Versus-Host Reactions in the Rat
}

\author{
Jan M. Langrehr, Noriko Murase, Peter M. Markus, Xin Cai, Peter Neuhaus, \\ Wolfgang Schraut, Richard L. Simmons, and Rosemary A. Hoffman \\ Department of Surgery, University of Pittsburgh, Pittsburgh, Pennsylvania 15261; and Department of Surgery, \\ Universitatsklinikum Rudolf-Virchow, Freie Universitat, 1000 Berlin 65, Germany
}

\begin{abstract}
The present study was designed to determine whether ${ }^{\circ} \mathrm{N}=\mathbf{O}$ produced in vivo during the rejection of histoincompatible tissues might permit serum $\mathrm{NO}_{2}^{-} / \mathrm{NO}_{3}^{-}$levels to serve as markers of a rejection reaction. Rat syngeneic and allogeneic liver, heart, bone marrow/spleen cell, small bowel, skin, and sponge matrix grafts were performed and the stable endproducts of $\mathrm{N}=\mathrm{O}, \mathrm{NO}_{2}^{-} / \mathrm{NO}_{3}^{-}$, were serially assayed in the serum of the grafted animals. A significant rise of serum $\mathrm{NO}_{2}^{-} / \mathrm{NO}_{3}^{-}$levels in the allografted animals preceded the onset of clinical signs of rejection or graft-versus-host disease, with the exception of the skin and sponge matrix graft models, where elevated serum $\mathrm{NO}_{2}^{-} / \mathrm{NO}_{3}^{-}$levels were never observed. In all transplant models, normal serum $\mathrm{NO}_{2}^{-} / \mathrm{NO}_{3}^{-}$levels were observed at all times in animals that received syngeneic grafts. Furthermore, treatment of allograft recipients with the immunosuppressive agents FK 506 or cyclosporine $A$ inhibited ${ }^{\circ} N=O$ production. Determination of serum creatinine levels demonstrated that the elevated serum $\mathrm{NO}_{2}^{-} / \mathrm{NO}_{3}^{-}$levels were not caused by kidney dysfunction. Serum $\mathrm{NO}_{2}^{-} / \mathrm{NO}_{3}^{-}$levels might be useful early serum markers of the initiation of a rejection reaction or graft-versushost disease when functional markers of graft dysfunction are not apparent. (J. Clin. Invest. 1992. 90:679-683.) Key words: rejection reaction $\bullet$ graft-versus-host disease $\bullet \mathrm{NO}_{2}^{-} / \mathrm{NO}_{3}^{-} \cdot \mathbf{F K}$ $506 \cdot$ Cyclosporine A
\end{abstract}

\section{Introduction}

The oxidative metabolism of L-arginine to its biologically active product, nitric oxide $(\mathrm{N}=\mathrm{O}),{ }^{1}$ is now known to be an important mediator of a variety of physiologic processes. Its

Address correspondence to Rosemary Hoffman, Department of Surgery, 497 Scaife Hall, University of Pittsburgh, Pittsburgh, PA 15261. The current address for Dr. Langrehr is Department of Surgery, URKV, Freie Universitat Berlin, Augustenburger Platz 1, 1000 Berlin 65 , Germany.

Received for publication 13 September 1991 and in revised form 10 April 1992.

1. Abbreviations used in this paper: BN, Brown-Norway (rat); CsA, cyclosporine A; GVHD, graft-versus-host-disease; ${ }^{\circ} \mathrm{N}=\mathrm{O}$, nitric oxide; $\mathrm{NO}_{2}^{-} / \mathrm{NO}_{3}^{-}$, nitrite/nitrate; $\mathrm{POD}$, postoperative day.

J. Clin. Invest.

(C) The American Society for Clinical Investigation, Inc.

$0021-9738 / 92 / 08 / 0679 / 05 \$ 2.00$

Volume 90, August 1992, 679-683 role as endothelial derived relaxing factor has been clearly defined. Endothelial cells contain a constitutive enzyme generating small quantities of ${ }^{\circ} \mathrm{N}=\mathrm{O}$, which, in turn, activates guanylate cyclase. This activation leads to elevated vascular and platelet levels of cyclic GMP inducing smooth muscle relaxation and platelet deaggregation (for review, see 1). Much larger amounts of ${ }^{\circ} \mathrm{N}=\mathrm{O}$ are generated by the nitric oxide synthase which can be induced by LPS and cytokines. In activated macrophages, $\mathrm{N}=\mathrm{O}$ seems to be responsible for important aspects of antimicrobial activity, a subject that has been extensively studied (for review, see 2).

These findings prompted us to investigate the significance of ${ }^{\circ} \mathrm{N}=\mathrm{O}$ synthesis during the course of an immune response to alloantigen. We demonstrated that inhibition of rat splenocyte mixed lymphocyte reactions is caused by ${ }^{\circ} \mathrm{N}=\mathrm{O}$ production within these cultures (3). Furthermore, we recently reported evidence that nitrite/nitrate $\left(\mathrm{NO}_{2}^{-} / \mathrm{NO}_{3}^{-}\right)$levels are elevated in the fluid surrounding rat sponge matrix allografts when compared to syngeneic grafts (4). The present experiments were designed to determine whether ${ }^{\circ} \mathrm{N}=\mathrm{O}$ production accompanied organ allograft rejection and graft-versus-host disease (GVHD) in vivo, and whether this production could serve as a "marker" of this immune response. Therefore, the stable endproducts of ${ }^{\circ} \mathrm{N}=\mathrm{O}$ synthesis, serum $\mathrm{NO}_{2}^{-} / \mathrm{NO}_{3}^{-}$levels were measured in untreated and immunosuppressed rats, receiving liver, heart, small bowel, skin, sponge matrix, and bone marrow/spleen cell allografts.

\section{Methods}

Animals. Male Lewis (RTI'), Brown-Norway $(\mathrm{BN})\left(\mathrm{RTI}^{\mathrm{n}}\right)$, and $\mathrm{ACI}$ $\left(\mathrm{RTI}^{2}\right)$ rats weighing 180-240 $\mathrm{g}$ were purchased from Harlan Sprague Dawley, Inc., Indianapolis, IN. All animals were maintained on a 12-h light/dark cycle and fed commercially available rat chow and tap water ad lib.

Experimental design. Lewis rats always served as recipients of either allogeneic or syngeneic transplants. BN or ACI rats served as allogeneic organ or cell donors. For each transplant model, an untreated allogeneic and syngeneic grafted group was prepared. Additionally, groups of syngeneic and allogeneic grafted animals (with the exception of sponge matrix and skin grafts) were treated with either Cyclosporine A (CsA) or FK 506. All animals were inspected and weighed daily, and serum was obtained on the postoperative days (POD) indicated. At least one time point for serum collection was chosen prior to the onset of clinical signs of rejection or GVHD. The experiments were terminated when the animals had completely rejected their grafts. The recipients of allografts being treated with CsA or FK 506 as indicated were followed for $30 \mathrm{~d}$ after cessation of the immunosuppressive therapy.

To determine whether serum $\mathrm{NO}_{2}^{-} / \mathrm{NO}_{3}^{-}$would decrease while an immune reaction spontaneously abates, orthotopic liver allografts 
from $\mathrm{BN}$ donors to Lewis recipients were carried out. This strain combination sustains an indefinite allograft survival without immunosuppressive therapy (5).

Materials. CsA (generously donated by Sandoz Inc., East Hanover, $\mathrm{NJ}$ ) was diluted in Intralipid (KabiVitrum Inc., Alameda, CA), and was injected intramuscularly. FK 506 (generously donated by Fujisawa Comp. Ltd., Osaka, Japan) was provided as a crystalline powder, suspended in saline, and injected intramuscularly.

Surgical procedures. Orthotopic liver transplantation was performed as previously reported (6). Recipient animals received Cefamandole Naftate ( $20 \mathrm{mg} / \mathrm{d}$ i.m.) (Eli Lilly and Company, Indianapolis, IN) for $3 \mathrm{~d}$ postoperatively.

Heterotopic heart transplantation was performed as previously described (6). Heart grafts were palpated daily and rejection was established when complete cessation of the heartbeat occurred and was confirmed by direct inspection at laparotomy.

Bone marrow/spleen cell transplantation was performed as previously described (7). Bone marrow and splenocyte single cell suspensions were prepared, and $30 \times 10^{6}$ splenocytes were mixed with 60 $\times 10^{6}$ bone marrow cells and injected intravenously into lethally irradiated $(1,000 \mathrm{R})$ recipients. The diagnosis of GVHD was made, when three of five clinical signs of GVHD (unkempt appearance, diarrhea, weight loss, dermatitis, or hyperkeratosis of the paws) were observed. Additionally, assessment of chimerism by FACS ${ }^{\circledR}$ analysis of peripheral blood mononuclear cells ( $\geq 90 \%$ donor cells) was performed, and histological evidence of GVH was obtained on skin sections.

One-step orthotopic small bowel transplantation was performed as previously described (8). A diagnosis of rejection was made when diarrhea and weight loss occurred.

Orthotopic skin transplantation was performed as previously described (9). The grafts were inspected daily after the casts were removed on POD 5, and rejection was considered complete when no residual viable graft epithelium could be seen.

Sponge matrix allografts were performed as previously described (4), by placing six polyurethane sponges subcutaneously into Lewis rats and immediately injecting $10 \times 10^{6} \mathrm{ACI}$ spleen cells into the sponges.

$F A C S^{\otimes}$ analysis. To assess engraftment of the bone marrow/spleen cell transplant, the presence of donor (ACI) type lymphocytes in the peripheral blood was determined using three different monoclonal antibodies (MAb 163, 211, and 42, kindly provided by Dr. H. W. Kunz, Department of Pathology, University of Pittsburgh) for detection of rat lymphocyte MHC class I antigens (10), analyzed on an Epics Profile Flow Cytometer (Coulter Electronics Inc., Hialeah, FL).

Blood chemistry and histology. Creatinine levels were measured for every serum sample obtained for $\mathrm{NO}_{2}^{-} / \mathrm{NO}_{3}^{-}$levels and never exceeded $0.8 \mathrm{mg} / \mathrm{dl}$ (normal for Lewis rats). Sections of the organ grafts or of the skin (from bone marrow/spleen cell grafts for detection of GVHD) from the recipients of allografts that were treated with CsA or FK 506 were fixed in formalin and prepared with hematoxylin and eosin stain for routine light microscopy.

$\mathrm{NO}_{2}^{-} / \mathrm{NO}_{3}^{-}$determination. After deproteinization (using $\mathrm{NaOH}$ and $\mathrm{Zn}_{2} \mathrm{SO}_{4}$ ) of the serum samples, the $\mathrm{NO}_{2}^{-} / \mathrm{NO}_{3}^{-}$concentration was determined using an automated colorimetric method based on the Griess reaction (11). Serum $\mathrm{NO}_{2}^{-} / \mathrm{NO}_{3}^{-}$values of normal Lewis rats (age 12-20 wk) ranged 8.8-32.2 $\mu \mathrm{M}$ (mean $\pm \mathrm{SEM}=18.93 \pm 1.3, n=18)$.

Statistical analysis. The results are expressed as mean \pm SEM and the unpaired Student's $t$ test was used to determine statistical significance. A $P$ value $\leq 0.05$ was considered to be of statistical significance.

\section{Results}

Liver grafts. Untreated Lewis recipients of BN liver allografts $(n=4)$ appeared healthy until POD 5-7, at which time reduced alertness, subsequent weight loss, icterus, and lethargy (POD 8-14) were observed. Gradual recovery from these symptoms was observed on POD 16-20, and the recipients appeared healthy again around POD 25 . The serum $\mathrm{NO}_{2}^{-} / \mathrm{NO}_{3}^{-}$levels of the allografted animals were significantly elevated on POD 5, 10 , and 15, and normal values were observed on POD 25 (Fig. 1). In contrast, animals that received syngeneic grafts $(n=3)$ were healthy, and normal $\mathrm{NO}_{2}^{-} / \mathrm{NO}_{3}^{-}$levels were detected during the entire observation period.

When Lewis recipients of $\mathrm{BN}$ liver allografts $(n=3)$ were treated with FK $506(0.5 \mathrm{mg} / \mathrm{kg}$ body wt per d) for $3 \mathrm{~d}$, the animals were healthy and normal serum $\mathrm{NO}_{2}^{-} / \mathrm{NO}_{3}^{-}$levels were observed at all time intervals after grafting (Fig. 1). Evidence of rejection was not detected upon histologic examination of the allografts at necropsy on POD 34 (data not shown).

Heart grafts. The first clinical sign of BN heart allograft rejection in Lewis recipients $(n=4)$ (palpable weakened heartbeat) was observed between POD 5 and 7 , with complete cessation of the heartbeat between POD 9 and 11 . The serum $\mathrm{NO}_{2}^{-} /$ $\mathrm{NO}_{3}^{-}$levels of the allografted animals were significantly elevated on POD 5 and returned to baseline levels on POD 10 (Fig. 2). A normal heartbeat was detected in the syngeneic grafts $(n=4)$ at all time intervals, and serum $\mathrm{NO}_{2}^{-} / \mathrm{NO}_{3}^{-}$levels were not elevated at any time.

Lewis recipients of $\mathrm{BN}$ heart allografts $(n=4)$ treated with FK 506 ( $1 \mathrm{mg} / \mathrm{kg}$ body wt per $\mathrm{d})$ for $3 \mathrm{~d}$ showed a normal heart beat upon palpation, and normal serum $\mathrm{NO}_{2}^{-} / \mathrm{NO}_{3}^{-}$levels were observed (Fig. 2). Histologic sections of the allografts, obtained at necropsy on POD 33, showed no signs of rejection (data not shown).

Small bowel grafts. Untreated Lewis recipients of ACI small bowel grafts $(n=6)$ deteriorated rapidly and died of an acute rejection after $7.2 \pm 0.8 \mathrm{~d}$. Significantly elevated $\mathrm{NO}_{2}^{-} /$ $\mathrm{NO}_{3}^{-}$serum levels were first detected in the allografted animals on POD 3 and were increased on POD 6 (Fig. $3 A$ ). The animals that received syngeneic grafts $(n=3)$ were healthy throughout the experiment, and normal $\mathrm{NO}_{2}^{-} / \mathrm{NO}_{3}^{-}$serum levels were detected.

When Lewis recipients of ACI $(n=4)$ or Lewis $(n=3)$ small bowel grafts were treated with CsA $(15 \mathrm{mg} / \mathrm{kg}$ body wt per day; POD 0-6 and POD 8-28 every other day), all animals were healthy until POD 45-50. Then diarrhea and successive weight loss occurred in the allograft recipients, and the animals were killed at a mean of $66 \pm 4.6 \mathrm{~d}$. The serum $\mathrm{NO}_{2}^{-} / \mathrm{NO}_{3}^{-}$levels of the allografted animals were slightly elevated on POD 30 and signif-

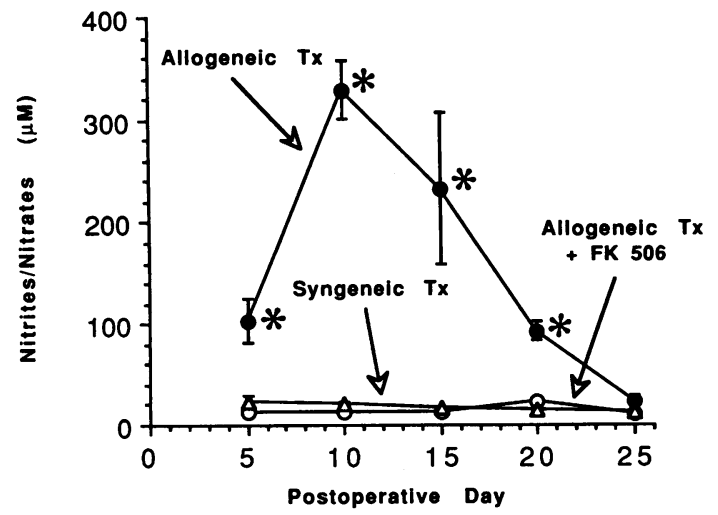

Figure 1. Syngeneic $(n=3)$ and allogeneic (with $[n=3]$ and without $[n=4]$ FK 506-treatment, day 0-2) orthotopic liver transplants were performed and the serum $\mathrm{NO}_{2}^{-} / \mathrm{NO}_{3}^{-}$levels were determined on the postoperative days indicated. Results are expressed as mean $\pm \mathrm{SEM}$; error bars not shown appear within the data point. ${ }^{*} P \leq 0.02$, comparing syngeneic and untreated allogeneic transplants. 


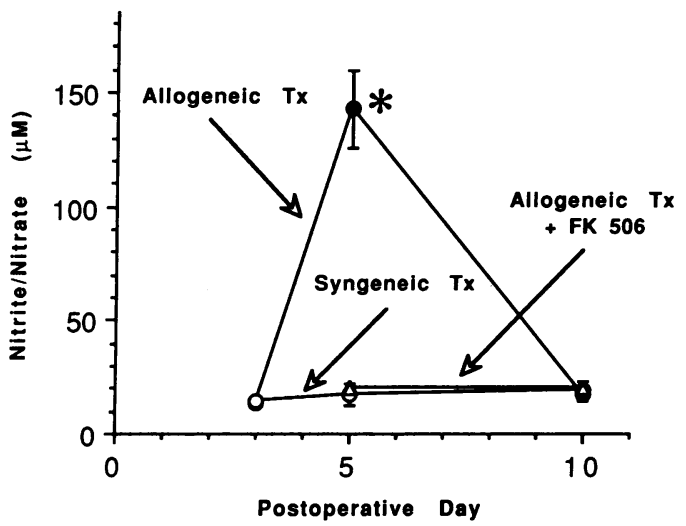

Figure 2. Syngeneic $(n=4)$ and allogeneic (with $[n=4]$ and without [ $n=4$ ] FK 506-treatment, day 0-2) heterotopic heart transplants were performed and the serum $\mathrm{NO}_{2}^{-} / \mathrm{NO}_{3}^{-}$levels were determined on the postoperative days indicated. Results are expressed as mean $\pm \mathrm{SEM}$; error bars not shown appear within the data point. ${ }^{*} P$ $\leq 0.02$, comparing syngeneic and untreated allogeneic transplants.

icantly elevated on POD 40 and 50, when compared to the values in animals that received syngeneic grafts (Fig. $3 \mathrm{~B}$ ). Histologic examination of the transplanted tissue on POD 40 ( $n$ $=3$ ), when allografted animals were still clinically healthy but the serum $\mathrm{NO}_{2}^{-} / \mathrm{NO}_{3}^{-}$levels were elevated, provided evidence of a mild chronic cellular rejection (data not shown).

Skin grafts. The onset of skin allograft rejection (erythema and epithelial necrosis) was observed between POD 7 and 9 ( $n$
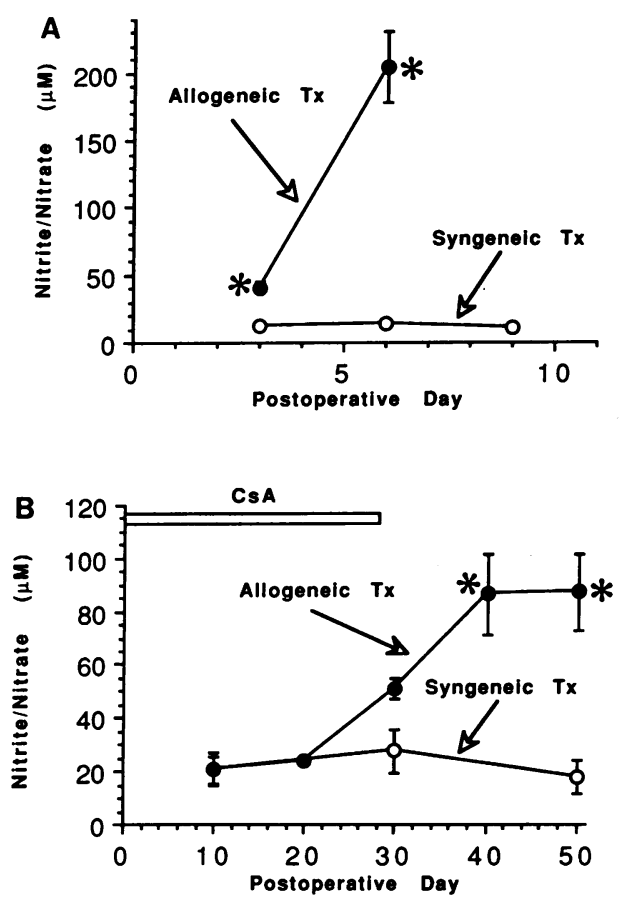

Figure 3. $(A)$ Syngeneic $(n=4)$ and allogeneic $(n=3)$ orthotopic small bowel transplants were performed. $(B)$ Syngeneic $(n=3)$ and allogeneic $(n=4)$ small bowel transplants were performed and treated with CsA ( $15 \mathrm{mg} / \mathrm{kg}$ body wt i.m.) on days $0-6$ and every other day from day 8 to 28 . The serum $\mathrm{NO}_{2}^{-} / \mathrm{NO}_{3}^{-}$were determined on the postoperative days indicated. Results are expressed as mean \pm SEM; error bars not shown appear within the data point. ${ }^{*} P \leq 0.01$, comparing syngeneic and allogeneic transplants.
$=5$ ) and complete rejection (i.e., total necrosis of the epidermis) was detected between POD 10 and 13. Syngeneic skin grafts $(n=3)$ were accepted without complication. Serum $\mathrm{NO}_{2}^{-} / \mathrm{NO}_{3}^{-}$levels, determined on POD $5,8,12$, and 16 , were not elevated in either group (Table I).

Sponge matrix grafts. As previously described, donor-specific cytotoxic $T$ lymphocytes at the graft site in this model were first detected on POD 6, peaked between POD 7-8, and waned by POD 10 (4). Serum $\mathrm{NO}_{2}^{-} / \mathrm{NO}_{3}^{-}$levels, determined on POD 4, 6, 8, and 10, were not elevated in either group (Table I).

Bone marrow/spleen cell grafts. The first clinical signs of GVHD in the Lewis recipients of ACI allografts $(n=8)$ were observed between POD 7 and 9. The animals developed diarrhea, lost weight, and when moribund, were killed at a mean of $21.3 \pm 1.7 \mathrm{~d}$. The $\mathrm{NO}_{2}^{-} / \mathrm{NO}_{3}^{-}$serum levels of the allografted animals were significantly elevated on POD 5, days before the first clinical signs of GVHD were observed. The levels remained elevated until the animals were killed (Fig. $4 \mathrm{~A}$ ). Lewis rats, which had been irradiated and reconstituted syngeneically ( $n$ $=6$ ) remained healthy and $\mathrm{NO}_{2}^{-} / \mathrm{NO}_{3}^{-}$serum levels remained normal throughout the experiment.

FK $506(1 \mathrm{mg} / \mathrm{kg}$ body wt per d) was administered to Lewis recipients of syngeneic $(n=8)$ bone marrow/spleen cell inocula on days $0-6$. $\mathrm{NO}_{2}^{-} / \mathrm{NO}_{3}^{-}$levels, monitored at various intervals until day 45, remained within normal range. FK 506 was also administered to Lewis recipients of allogeneic bone marrow/ spleen cell inocula on days $0-6(n=10)$ or days 7-21 $(n=7)$ postgrafting. Administration of FK 506 on days 0-5 resulted in a delayed elevation of serum $\mathrm{NO}_{2}^{-} / \mathrm{NO}_{3}^{-}$levels when compared to untreated animals. Administration of FK 506 on days 7-12 postgrafting resulted in a dramatic decrease in serum $\mathrm{NO}_{2}^{-} /$ $\mathrm{NO}_{3}^{-}$levels from pretreatment values on day 7 to values obtained on day 13, when the animals had received FK 506 for 7 d (Fig. 4 B). As described by Markus et al. (7), FK 506 treatment of Lewis recipients of ACI allogeneic bone marrow/ spleen cell inocula, results in detection of donor cell (ACI) engraftment in these recipients on POD 30 and prolonged survival compared to untreated animals (data not shown).

\section{Discussion}

The discovery that $\mathrm{N}=\mathrm{O}$ is produced by cells of the monocyte-macrophage lineage in response to inflammatory cyto-

Table I. Serum $\mathrm{NO}_{2}^{-} / \mathrm{NO}_{3}^{-}$Levels in Lewis Recipients of $\mathrm{ACI}$ or Lewis Skin Grafts or Sponge Matrix Grafts on Various Days Postgrafting

\begin{tabular}{lcccc}
\hline & \multicolumn{5}{c}{ Postoperative day } \\
\cline { 2 - 5 } \multicolumn{1}{c}{ Skin grafts } & 5 & 8 & 12 & 16 \\
\hline Allogenic $(n=5)$ & $27.3 \pm 2.9$ & $18.1 \pm 2.4$ & $14.2 \pm 0.9$ & $18.5 \pm 1.7$ \\
Syngeneic $(n=3)$ & $18.7 \pm 2.2$ & $16.0 \pm 3.3$ & $15.7 \pm 0.3$ & $19.0 \pm 0.8$ \\
& & & & \\
Sponge matrix grafts & 4 & 6 & 8 & 10 \\
Allogeneic $(n=3)$ & $11.8 \pm 1.5$ & $21.6 \pm 3.0$ & $17.7 \pm 1.6$ & $17.3 \pm 4.9$ \\
Syngeneic $(n=3)$ & $11.3 \pm 0.7$ & $18.2 \pm 3.3$ & $22.1 \pm 2.7$ & NT* $^{*}$ \\
& & & & \\
\hline
\end{tabular}

Blood was obtained from recipients of allogeneic and syngeneic skin and sponge matrix grafts at the postoperative days indicated and the serum $\mathrm{NO}_{2}^{-} / \mathrm{NO}_{3}^{-}$levels were determined. Results are expressed as mean \pm SEM. * NT, not tested. 

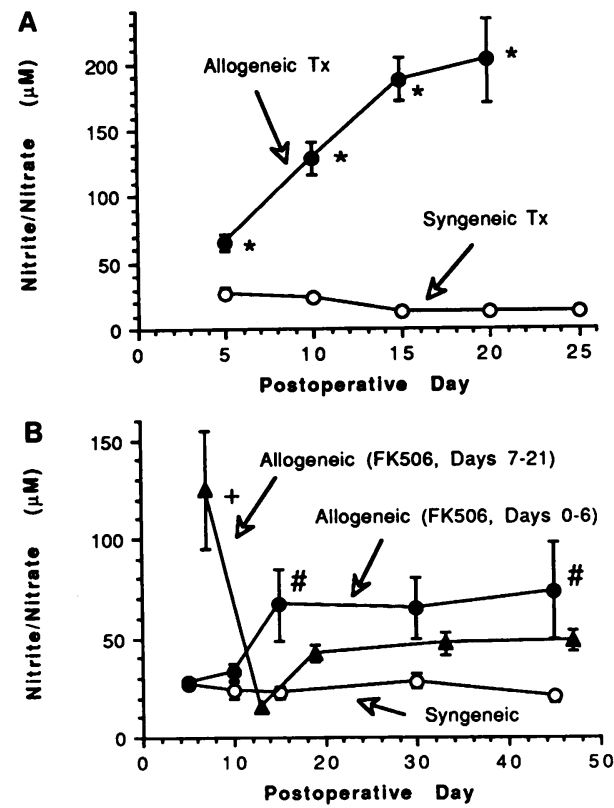

Figure 4. $(A)$ Syngeneic $(n=6)$ and allogeneic $(n=8)$ bone marrow/ spleen cell transplants were performed. $(B)$ Syngeneic $(n=8)$ and allogeneic bone marrow/spleen cell transplants were performed. FK 506 was administered $(1 \mathrm{mg} / \mathrm{kg}$ body wt i.m.) on days $0-6(n=10)$ or on days 7-21 $(n=7)$. The serum $\mathrm{NO}_{2}^{-} / \mathrm{NO}_{3}^{-}$levels were determined on the postoperative days indicated. Results are expressed as mean \pm SEM. ${ }^{*} P \leq 0.01{ }^{*} P \leq 0.05$, comparing syngeneic and allogeneic transplants; ${ }^{\dagger} P \leq 0.01$, comparing days 7 and 13 in the group treated with FK 506 on days 7-21.

kines such as IL-1, tumor necrosis factor, and IFN $\gamma$ initiated our investigation into the possible immunomodulating effects of ${ }^{\circ} \mathrm{N}=\mathrm{O}$ on the allograft response. Initially, we showed that the inhibition of lymphocyte proliferation in rat splenocyte mixed lymphocyte cultures coincided with high $\mathrm{NO}_{2}^{-} / \mathrm{NO}_{3}^{-} \mathrm{lev}$ els in the culture supernatants, and that this inhibition was reversed by the addition of $\mathrm{N}^{\mathrm{G}}$-monomethyl-L-arginine (NMA), the competitive inhibitor of ${ }^{\circ} \mathrm{N}=\mathrm{O}$ synthesis (3). In a subsequent study, we showed that cells infiltrating sponge matrix allografts produce more $\mathrm{N}=\mathrm{O}$ spontaneously than cells which have infiltrated a syngeneic graft, and that allospecific cytolytic activity of cultured allograft infiltrating lymphocytes was observed only when NMA was added to the cultures. Additionally, macrophages, which have been shown in a number of studies to be a major subpopulation of graft infiltrating cells (12), were responsible for most of the $\mathrm{N}=\mathrm{O}$ produced by the sponge graft infiltrating cells (4). The ${ }^{\circ} \mathrm{N}=\mathrm{O}$-induced inhibition of lymphocyte proliferation has subsequently been confirmed by others using mitogen-stimulated rat splenocyte cultures $(13,14)$.

Barbul has demonstrated that in lymphocytes, L-arginine is converted to picomolar quantities of ${ }^{\circ} \mathrm{N}=\mathrm{O}$, which may be essential for lymphocyte responses (15). In contrast, the large amount of ${ }^{\circ} \mathrm{N}=\mathrm{O}$ produced in macrophage lymphocyte cocultures inhibits lymphocyte proliferation $(3,4,13,14,16)$. In all culture systems studied thus far, including the rat splenocyte mixed lymphocyte reaction and rat sponge allograft infiltrating cells cultured with alloantigen, IL-2 production is detected and the inhibition of $T$ lymphocyte proliferation occurs because $T$ cells are unable to use the cytokines that are produced $(3,16)$.
The present communication demonstrates for the first time that total body $\mathrm{N}=\mathrm{O}$ production is increased during the rejection of vascularized organ allografts and in GVHD. In all vascularized allograft models and the GVHD model, a significant rise in serum $\mathrm{NO}_{2}^{-} / \mathrm{NO}_{3}^{-}$levels was detected before clinical signs of rejection or GVHD were observed. In the $\mathrm{BN}$ to Lewis liver allograft model, a decrease of the serum $\mathrm{NO}_{2}^{-} / \mathrm{NO}_{3}^{-}$levels paralleled the dissolution of the rejection reaction. Furthermore, it is clear that ${ }^{\circ} \mathrm{N}=\mathrm{O}$ production requires the initiation of an immune response, since elevated serum $\mathrm{NO}_{2}^{-} / \mathrm{NO}_{3}^{-}$levels were never detected in animals that received syngeneic grafts. However, recipients of skin allografts and sponge matrix allografts showed no detectable change from normal serum $\mathrm{NO}_{2}^{-} /$ $\mathrm{NO}_{3}^{-}$levels before and during allograft rejection. Obvious differences such as size of the allograft and the fact that neither skin nor sponge matrix allografts are initially vascularized may account for the lack of elevation in serum $\mathrm{NO}_{2}^{-} / \mathrm{NO}_{3}^{-}$levels. In the sponge allograft model, small but significantly increased $\mathrm{NO}_{2}^{-} / \mathrm{NO}_{3}^{-}$levels were found in the fluid surrounding the allograft matrix (4), but rapid excretion of $\mathrm{NO}_{2}^{-} / \mathrm{NO}_{3}^{-}$may prevent its detection in the serum. Since the number of graft infiltrating cells recovered from an acutely rejecting heart allograft in the rat (12) is comparable to the number of cells recovered from a sponge allograft (4), the failure to find elevated serum $\mathrm{NO}_{2}^{-} /$ $\mathrm{NO}_{3}^{-}$in the recipients of sponge allografts may relate to the nature of the vascularization between the two allograft models.

The serum $\mathrm{NO}_{2}^{-} / \mathrm{NO}_{3}^{-}$of the recipients of various organ and bone marrow/spleen cell allografts remained normal during therapy with CsA or FK 506. This finding confirms our previous in vitro observation, in which addition of FK 506 to cultures of sponge graft infiltrating cells plus alloantigen completely inhibited $\mathrm{N}=\mathrm{O}$ production, presumably due to inhibition of T cell cytokine production by FK 506 (16). However, when the immunosuppressive therapy was terminated and histologic evidence of recurring rejection or GVHD was ultimately detected (in the small bowel and the bone marrow/ spleen cell transplants), elevated $\mathrm{NO}_{2}^{-} / \mathrm{NO}_{3}^{-}$levels were detected. In contrast, FK 506-treated liver and heart allograft recipients not only maintained normal serum $\mathrm{NO}_{2}^{-} / \mathrm{NO}_{3}^{-}$levels, but also maintained normal graft function. Thus, these data suggest that the detection of elevated serum $\mathrm{NO}_{2}^{-} / \mathrm{NO}_{3}^{-}$ levels in recipients of vascularized allografts correlates well with the rejection reaction. Serum $\mathrm{NO}_{2}^{-} / \mathrm{NO}_{3}^{-}$levels may possibly prove to be an early marker of graft rejection, but the clinical utility of such an assay is, as yet, untested. It is quite probable that endothelial cell derived $\mathrm{N}=\mathrm{O}$ also plays a role in vascularized allograft rejection. However, the amount of $\mathrm{N}=\mathrm{O}$ produced via the constitutive pathway is quite small compared to the inducible pathway and thus is not likely to be a significant component of the serum $\mathrm{NO}_{2}^{-} / \mathrm{NO}_{3}^{-}$levels measured here.

Many reports now exist documenting increased serum $\mathrm{NO}_{2}^{-} / \mathrm{NO}_{3}^{-}$and/or elevated urinary excretion of $\mathrm{NO}_{2}^{-} / \mathrm{NO}_{3}^{-}$ after administration of immunostimulatory agents such as LPS, Bacillus Calmette-Guérin, or C. parvum in rats and mice. Thus, it is clear that elevated $\mathrm{NO}_{2}^{-} / \mathrm{NO}_{3}^{-}$levels are indicative of initiation of a cellular immune reaction, similar to elevated neopterin levels (17) and are not specific for allograft rejection. In addition, although serum creatinine levels were normal for all animals in this study, we cannot rule out possible alterations in renal tubular secretion of $\mathrm{NO}_{3}^{-}$. However, a report by Wagner et al. (18) demonstrating that LPS treatment of rats did 
not alter nitrate clearance makes this possibility unlikely. Also, possible defects in $\mathrm{NO}_{2}^{-} / \mathrm{NO}_{3}^{-}$clearance by other organs in an allografted animal resulting in elevated serum $\mathrm{NO}_{2}^{-} / \mathrm{NO}_{3}^{-}$cannot be ruled out. Since urinary nitrate excretion accounts for $60-70 \%$ of nitrate clearance from the body (19), other mechanisms of elimination clearly exist but are not known at this time.

The recent report by Werner-Felmayer et al. demonstrating that murine fibroblast production of $\mathrm{NO}_{2}^{-} / \mathrm{NO}_{3}^{-}$in culture is dependent on the presence of tetrahydrobiopterin (20) adds another perspective to our findings. Neopterins are formed as the result of cytokine-induced stimulation of GTP-cyclohydrolase I, which cleaves GTP to 7,8-dihydroneopterin triphosphate (excreted as 7,8-dihydroneopterin and 5,6,7,8-tetrahydrobiopterin an essential cofactor for various monooxygenases [reviewed in 17]). Several investigators reported that a rise in serum and urine neopterin levels was an early marker of a cellular immune response in some patients undergoing allograft rejection (reviewed in 17). It is therefore conceivable that the elevated $\mathrm{NO}_{2}^{-} / \mathrm{NO}_{3}^{-}$serum levels seen in our studies reflect the increased availability of 5,6,7,8-tetrahydrobiopterin, a necessary cofactor for $\mathrm{N}=\mathrm{O}$ synthesis.

Using electron paramagnetic resonance (EPR) spectroscopy, which can directly detect ${ }^{\circ} \mathrm{N}=\mathrm{O}$, bound, for example, to hemoglobin, Lancaster and Hibbs were able to prove that cytokine-activated macrophages possess the characteristic iron-nitrosyl signal, specific for ${ }^{\circ} \mathrm{N}=\mathrm{O}(21)$. Subsequently, Drapier et al. demonstrated that the macrophage-derived $\mathrm{N}=\mathrm{O}$ can be detected in the mitochondria of target cells after coculture (22), where it possibly exerts its known inhibitory effect on several mitochondrial enzymes (23). In a recent study, we have observed that EPR-detectable $\mathrm{N}=\mathrm{O}$ is produced in a heart allograft rejection model and can be localized to the rejecting allograft and the blood, but not to other organ sites (24). Since we have previously shown in vitro that $\mathrm{N}=\mathrm{O}$ production during the response to alloantigen inhibits lymphocyte proliferation $(3,4,16)$, it is conceivable that $\mathrm{N}=\mathrm{O}$ synthesis might be a regulatory effector mechanism in vivo also. However, whether the $\mathrm{N}=\mathrm{O}$ produced in vivo can in fact delay the rejection process by inhibiting lymphocyte function remains to be determined.

Serum $\mathrm{NO}_{2}^{-} / \mathrm{NO}_{3}^{-}$levels may well prove to be a useful marker of the rejection of vascularized allografts and GVHD. The measurement of $\mathrm{NO}_{2}^{-} / \mathrm{NO}_{3}^{-}$in serum and urine is simple and reliable, and may provide evidence of an even mild controlled rejection or GVHD, which otherwise would prove difficult to detect by conventional assays of organ function or other methods of immunological monitoring. Whether $\mathrm{NO}_{2}^{-} / \mathrm{NO}_{3}^{-}$ levels will increase during viral or other opportunistic infections is presently unknown.

\section{Acknowledgments}

The authors wish to thank Dr. H. W. Kunz, Department of Pathology, University of Pittsburgh for supplying the antibodies, Dr. B.-C. Gottwald for critical review of the manuscript and Rebecca Pfeiffer for excellent secretarial assistance.

This work was supported by National Institutes of Health grants AI-16869 and GM-37753 to Dr. Richard L. Simmons. Dr. Jan M. Langrehr and Dr. Peter M. Markus are supported by the German Research Council, (La-621/2-2) and (Ma-114a/2-1), respectively.

\section{References}

1. Ignarro, L. J. 1990. Biosynthesis and metabolism of endothelium-derived nitric oxide. Annu. Rev. Pharmacol. Toxicol. 30:535-560.

2. Nathan, C. F., and J. B. Hibbs, Jr. 1991. Role of nitric oxide synthesis in macrophage antimicrobial activity. Curr. Opin. Immunol. 3:65-70.

3. Hoffman, R. A., J. M. Langrehr, T. R. Billiar, R. D. Curran, and R. L. Simmons. 1990. Alloantigen-induced activation of rat splenocytes is regulated by the oxidative metabolism of L-arginine. J. Immunol. 145:2220-2226.

4. Langrehr, J. M., R. A. Hoffman, T. R. Billiar, K. K. W. Lee, W. H. Schraut, and R. L. Simmons. 1991. Nitric oxide synthesis in the in vivo allograft response: A possible regulatory mechanism. Surgery (St. Louis). 110:335-342.

5. Zimmerman, F. A., H. F. S. Davies, P. P. Knoll, J. M. Gokel, and T. Schmidt. 1984. Orthotopic liver graft in the rat. The influence of strain combination on the fate of the graft. Transplantation (Baltimore). 37:406-410.

6. Murase, N., D. G. Kim, S. Todo, D. V. Cramer, J. J. Fung, and T. E. Starzl. 1990. Suppression of allograft rejection with FK 506. I. Prolonged cardiac and liver survival in rats following short-course therapy. Transplantation (Baltimore). 50:186-189.

7. Markus, P. M., X. Cai, W. Ming, A. J. Demetris, J. J. Fung, and T. E. Starzl. 1991. FK 506 reverses acute graft-versus-host disease following allogeneic bone marrow transplantation in rats. Surgery (St. Louis). 110:357-364.

8. Langrehr, J. M., K. K. W. Lee, M. E. Wachs, T. K. Lee, M. J. Stangl, R. Venkataramanan, H. W. Kunz, and W. H. Schraut. 1990. Comparison of the effectiveness of cyclosporine $A$ in small-bowel transplantation using different rat strain combinations. Transplant. Proc. 22:2533-2535.

9. Ildstad, S. T., S. M. Wren, S. O. Sharrow, D. Stephany, and D. H. Sachs. 1984. In vivo and in vitro characterization of specific hyporeactivity to skin xenografts in mixed xenogenetically reconstituted mice (B10 + F344 Rat $\rightarrow$ B10). J. Exp. Med. 160:1820-1835.

10. Gill, T. J. III, W. H. Kunz, D. N. Misra, and A. L. Cortese-Hassett. 1987. The major histocompatibility complex of the rat. Transplantation (Baltimore). 43:773-778.

11. Green, L. C., D. A. Wagner, J. Glogowski, P. L. Skipper, J. S. Wishnok, and S. R. Tannenbaum. 1982. Analysis of nitrate, nitrite and $\left({ }^{15} \mathrm{~N}\right)$ nitrate in biological fluids. Anal. Biochem. 126:131-138.

12. Araujo, J.-L., J. W. Kupiec-Weglinski, D. Araneda, E. Towpik, C. D. Heidecke, J. M. Williams, and N. L. Tilney. 1985. Phenotype, activation status, and suppressor activity of host lymphocytes during acute rejection and after cyclosporine-induced unresponsiveness of rat cardiac allografts. Transplantation (Baltimore). 40:278-284.

13. Mills, C. D. 1991. Molecular basis of "suppressor" macrophages. Arginine metabolism via the nitric oxide Synthetase pathway. J. Immunol. 146:27192723.

14. Albina, J. E., J. A. Abate, and W. L. Henry, Jr. 1991. Nitric oxide production is required for murine resident peritoneal macrophages to suppress mitogenstimulated T cell proliferation. Role of IFN $\gamma$ in the induction of the nitric oxidesynthesizing pathway. J. Immunol. 147:144-148.

15. Efron, D. T., S. J. Kirk, M. C. Regan, H. L. Wasserkrug, and A. Barbul. 1991. Nitric oxide generation from L-arginine is required for optimal human peripheral blood lymphocyte DNA synthesis. Surgery (St. Louis). 110:327-334.

16. Langrehr, J. M., K. E. Dull, J. B. Ochoa, T. R. Billiar, S. T. Ildstad, W. H. Schraut, R. L. Simmons, and R. A. Hoffman. 1992. Nitric oxide production by in vivo allosensitized cells inhibits the development of allospecific CTL. Transplantation (Baltimore). 53:632-640.

17. Wachter, H., D. Fuchs, A. Hausen, G. Reibnegger, and E. R. Werner. 1988. Neopterin as marker for activation of cellular immunity: immunologic basis and clinical application. Adv. Clin. Chem. 27:81-141.

18. Wagner, D. A., V. R. Young, and S. R. Tannenbaum. 1983. Mammalian nitrate biosynthesis: Incorporation of ${ }^{15} \mathrm{NH}_{3}$ into nitrate is enhanced by endotoxin treatment. Proc. Natl. Acad. Sci. USA. 80:4518-4521.

19. Wagner, D. A., D. S. Schultz, W. M. Deen, V. R. Young, and S. R. Tannenbaum. 1983. Metabolic fate of an oral dose of N-labeled nitrate in human effect of diet supplementation with ascorbic acid. Cancer Res. 43:1921-1925.

20. Werner-Felmayer, G., E. R. Werner, D. Fuchs, A. Hausen, G. Reibnegger, and $H$. Wachter. 1990. Tetrahydrobiopterin-dependent formation of nitrite and nitrate in murine fibroblasts. J. Exp. Med. 172:1599-1607.

21. Lancaster, J. R., J. B. Hibbs, Jr. 1990. EPR demonstration of iron-nitrosyl complex formation by cytotoxic activated macrophages. Proc. Natl. Acad. Sci. USA. 87:1223-1227.

22. Drapier, J.-C., C. Pellat, and Y. Henry. 1991. Generation of EPR-detectable nitrosyl-iron complexes in tumor target cells cocultured with activated macrophages. J. Biol. Chem. 266:10162-10167.

23. Stuehr, D. J., and C. F. Nathan. 1989. Nitric oxide. A macrophage product responsible for cytostasis and respiratory inhibition in tumor target cells. J. Exp. Med. 169:1543-1555.

24. Lancaster, Jr., J. R., J. M. Langrehr, H. A. Bergonia, N. Murase, R. L. Simmons, and R. A. Hoffman. 1992. EPR detection of heme and nonheme iron-containing protein nitrosylation by nitric oxide during rejection of rat heart allograft. J. Biol. Chem. 267:10994-10998. 